\title{
BACTERIOLOGICAL AND CLINICAL STUDIES ON MICROCOCCI WHICH WERE FOUND IN THE MIDDLE EAR EXUDATE.
}

\author{
By \\ C. YOSHIE \\ From the Department of Bacteriology, School of Medicine, Kanazawa University. \\ (Prof: T. Tani M.D.)
}

National Kanazawa Hospital. (Director: T. Tanemura, M.D.)

One hundred and sixty-two strains of micrococci which were obtained from the exudate in the middle ear of acute or chronic otitis media, were classified after Hucker and Hall's method, in which 112 strains were pathogenic and so staius were non-pathogenic. Pathogenicity of each strain was further studied by animal inoculation and other methods and it was found that 106 strains were pathogenic and 56 strains were non-pathogenic. Although there was slight diocrepancy in the results of the clas sification, Hucker and Hall's methods was thought to be satisfactory for otological bractice, becance of it's simplicity.

In the acute cases, 3 out of 12 cases or $25 \%$ and in the chronicases, 13 out 38 or $38 \%$ were resistant to penicillin, Also in the acute cases, 3 out of 12 or $25 \%$ and 10 out of 38 cases or $38 \%$ were resistant to sulfathiazol.

In acute otitismedia, the incidence of the demonstration of micrococci was high among the cases under 1 year of age, and it was very low among the cases over 5 years of age. In chronic otitis media, the incidence was high among the cases between the age of 5 and 25 .

Prognosis of the acute otitis media dueto micrococoi was generally favorable although in 7 out of 31 cases without mixed infection, convalescence was prolonged and in 2 cases, the disease was followed by chronic otitis media. In the cases with mixed infection, chromic otitis media followed in 3 out of 12 cases. Micrococci, especially micrococcus pyogenes appeared to have atendency to aguive drug-fastness easily.

\section{中耳炎分泌液より検出せる Micrococcus の微生物学的 並に耳科臨休的研究}

金沢大学医学部微生物学教空専攻生（主任：谷 友次漖授)

国立金沢病院耳: 稀咽喉科（医長：種村竜夫博士）

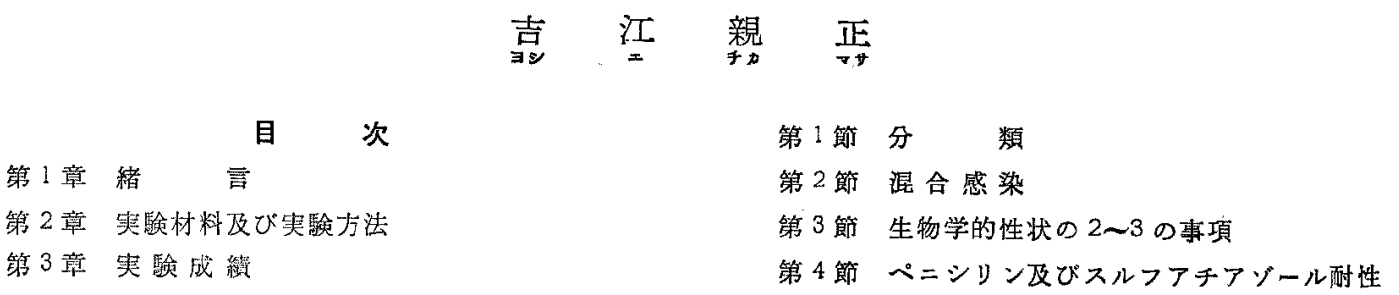


第 5 節 臨休との関係

1 中耳分泌液の性状

2 年令的関係

3 鼓䠜穿孔

$4 \mathrm{Mic}$ を検出した急性中耳炎の予後

5 慢性症例に拈ける菌の変遷

第 4 章 総括並に考按

第 5 章 結琣

主要文献

第1章 緒言

急性中耳炎及び慢性中耳炎の分泌液より球菌を榆出す る頻度は極めて高く中耳炎の起炎菌として重要な役割 をしているため, 古くから幾多の業績をみるとこるであ る.殊にブドウ球菌については種々な角度から，稓々な 方法で研究されている．しかし細菌学の発達により，根 幹である分類に和いても幾多の変遷をきたし，1943年 朄の Hucker は球菌属の 分類中へ，ブドウ球菌属を 合併して分類を更新した。更に好気性球菌に加え，婎気 性球菌の分類は1944 年 Hall によつて一部改正され, 現今の Bergey の新分類法が確立されるに至つた。

ブドウ球菌は諸種の新化学製刘に感性が高く，本菌に よる中耳炎の治澺成綪はスルフフ剤並にペニシリン，そ

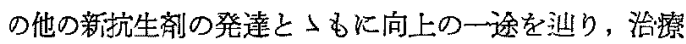
上良好な結果を収めてきた。しかるに最近に至りプドウ 球菌による中耳炎の治滰小遷延し，慢性化の傾向が認的 られ，菌の性状の変化，㭼剂酎牲の出現等が報告される に至つた.

わたくしはこ」に Micrococcus の渐分類法により， 中耳分泌液の球菌を分類し, 細菌学的に久耳科陪床との 関係沉いて観察，報告する。

\section{第 2 章 实験材料及び実験方法}

1950 年 10 月から 1953 年 3 月に至る满 2 力 年半の間 に，国立金沢病院耳鼻咽唉科外来及び入院の患者につい て, 中耳分泌液中より検出した Micrococcus 162 例に ついて本検䇣を施行した。これを表示すると第1表のよ らである。

検査材粘・採取：外耳道を清拭，消毒した後，予め 乾熱隇菌せる駒入毛細管ピペツトをもつて，战室内から 直接分泌液を吸引㥒取した，即ら非穿孔性症例，穿孔の 極めて小さな症例については鼓膜切開により，穿孔の中 等大以上の症例はその穿孔を介し，贡余りに污梁されて いる慢性中耳炎では 1 回乃至数回治療した後，清浄とな るを待つて頭室内分泌液を採取した。
第 1 表 Micrococcus 実駼症例

\begin{tabular}{|c|c|c|c|c|c|}
\hline & 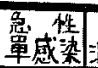 & 1 & 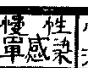 & & \\
\hline 950 & & & & & \\
\hline 951 & .14 & 10 & 2? & I0 & 56 \\
\hline 1952 & 20 & 8 & 38 & 20 & 86 \\
\hline 150 & 3 & 2 & 5 & 1 & 14 \\
\hline 話 & 38 & 21 & 68 & & Ih? \\
\hline
\end{tabular}

检查材粗の処置: 採取後 $1.0 \mathrm{cc}$ 隇菌 生理食塩水に浮

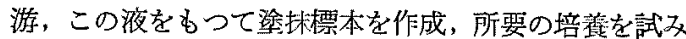
た。

染色標本，算染色，グラム染色，扮酸性染色を施行し た。

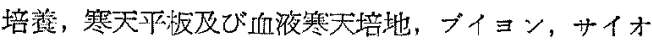
グリコレイト培地以培㹶し，その後分離，分類培讙を試 みた。

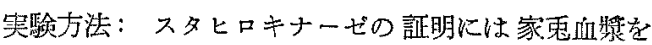
使用した。溶血性検査には家患赤血球 寒天平板を用い た。楟分解はペプトン水に0.5〜1.0\%に糖を加へ，24㭙

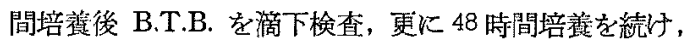
再び1〜2滴の B.T.B. を加へ検査した。ペニシリン耐 性檢查には寒天培地入混积，階政桸粎とし，スルフアチ アゾールは $10 \%$ サルゾール-S を半合成成液体培地へ稀 釈, 培竞した。

中耳分泌液の色及び性状については吸收採取液につい て検查した。

第1節 分 類

Micrococcus の分類は Bergey 著 Manual of Dete-

第 2 表 分 類

\begin{tabular}{|l|r|r|r|r|r|}
\hline & & & & \\
\hline
\end{tabular}

註 $32 / 38$ は检査数 38 株:の中, 病原性のもの32株 あるを示す，その他はこれに準ず 
rminative Bacteriology. 6版により施行した、その結 果は第 2 表のようである.

以上の実歌成績を病原性と非病原性株に一括表示する と第3表のよらである。

第 3 表 分類上の病原性

\begin{tabular}{|c|c|c|}
\hline & 病原株 & 非病原窥 \\
\hline 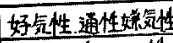 & 107 & 49 \\
\hline 嫌気性 & 5 & I \\
\hline 計 & 112 & 50 \\
\hline
\end{tabular}

即々 112 株に病原性があり，50株㤝非病原性である と分類上は決定された。

第 2 節 混合感染

急性及び慢性中耳炎から Micrococcus を証明した症 例に混合感染していた細菌との関倸は第 4表のようであ る.

第 4 表 混合感染菌株

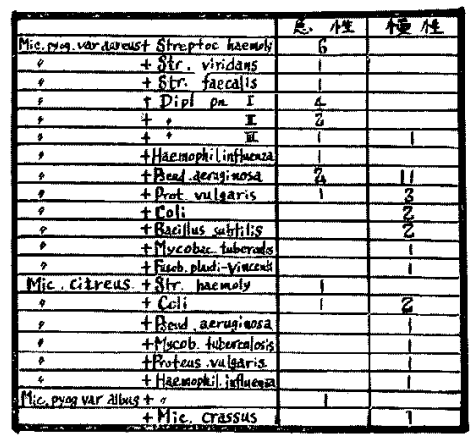

急性中耳炎では溶血性レンサ 球菌, 肺资双球菌が多 くイレフルエンザ菌との混合感染は1例双られたに過 ぎない.

慢性中耳炎では椂㖶菌が最も多く，变形菌大腸菌がこ れについでいた。

3 菌程混合のもの\& 2 例認めた。

第 3 節 生物学的性状の 2 3の牙項

(1) Coagulase test: 尖験聇例全株についてスタと ロキナーゼの检查を行うに，その成鼣は第 5 表のようで ある。

检査成猜上（土）の7 例及び一部臨床上病原菌として

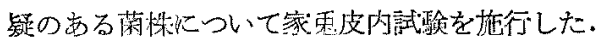

その結果分粯上 Mic, Pyog. V. aureus と決定して Coagulas test 疑陽性であつた 4 株中 2 株は家鬼皮内試
第 5 表 Coagulase test

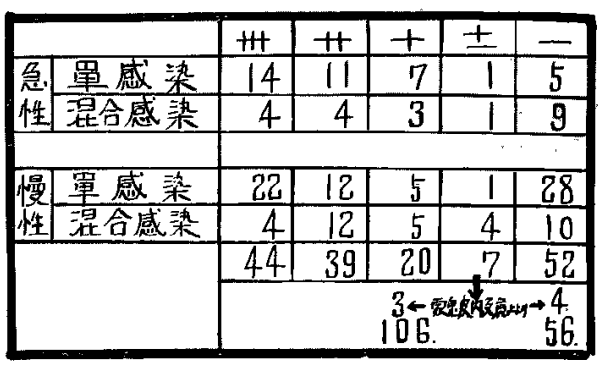

験陽性，2株は隆性.Mic, citreus 02 株中, 1 株は陽

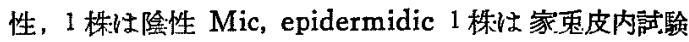
㓌性であつた。臨床上病原性に疑をおいた各株はいずれ む Bergey の分類と Coagulase test と成續が一致し た．分類上病原性がある株として決定された菌株中 6 株, 即方 Mic. p. v. aureus 2 株, Mic. p. v. albus. 3 株, Mic. epidermidis. 1 株は Coagulase test 及び家 鬼皮内試験により非病原性株であろうとた。分類上病 原株と泆定した112株中 Coagulase test 陽性のもの 103 株，㫐陽性で家鬼皮内試験により陽性を示した 3 株 を加へ，106株加病原性菌株と認めた。

(2) 溶血作用: 家鬼 血夜 平板寒天培地，24 時間培 盖の成績は第6表のようである.

第 6 表 溶 血 作 用

\begin{tabular}{|c|c|c|c|c|c|c|}
\hline & 急覃感染 & 色湂感棐 & 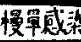 & 曼混感 & 計 & $\%$ \\
\hline 㑂原性株 & $21 / 29$ & $7 / 10$ & $88 / 38$ & $14 / 24$ & 69 & 1905 \\
\hline 非病睡性 & $1 / 6$ & $1 / 0$ & $7 / 8 ?$ & $3 / 9$ & & if? \\
\hline
\end{tabular}

註 表中分母は施行䏭数，分子は溶血株数を示与

溶血環の性状はや」不同で，大きさも大小区々であつ た.

病原株 101 中 69 株即万 $70.5 \%$ に, 非病原株 49 の中 12 株即ら $24.2 \%$ に溶血作用を認めた。

（3）粰分解：つざの10柇について施行した，即ち Mic. p. v. aureus. 5 株. Mic. p. v. albus. 2 株. Mic, citreus 2 株. Mic. epidermidis 1 株で, その成績は第 7 表のよらである。

マンニットは Mic, p. v. aureus \& albus もともに 分解されるとされているが，本試験では分解は遅く且つ 除性に近い株があつた。

ラクトーゼやグリセロールは分解が遅いが陽性を示し 
第 7 表 糖 分 解

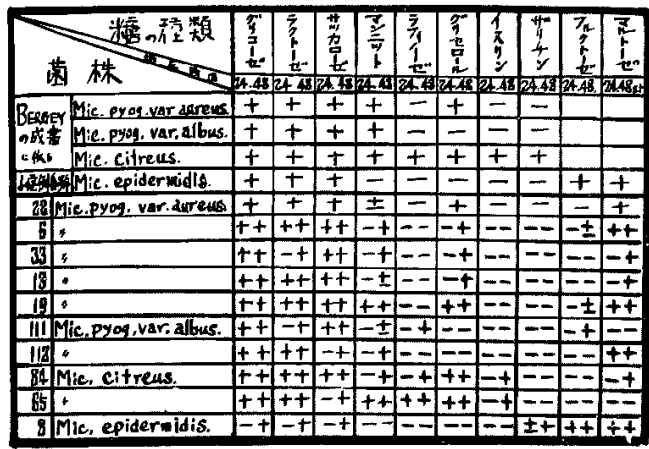

註（1）表中上部の”24，48 とは培裳時間を示す

(2) 症例中前 22 は 24 時間 1 回の成縝である.

（3）（士）とは B.T.B.を㒖か飞脱色するも，赤 黄変をきたさない陰性に近い成䋏を示す

た.

粘分野は文献とほよ゙同様であつたが一部その菌株によ り相違があった。

第 4 節 ペニシリン及びスルフフチアゾール耐性

ペニシリン及びサルゾールーS の感性を 50 株について 検査した成積を一括すると第8表のようである。

第 8 表 薬 剂 酎 性

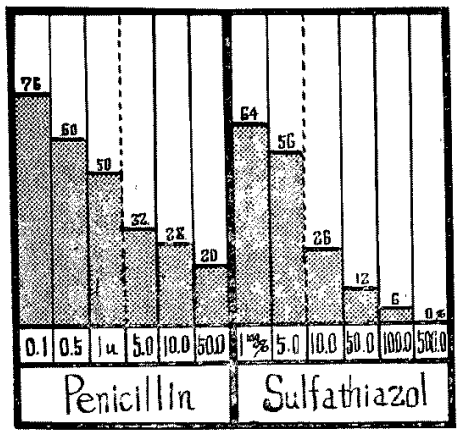

プドウ球菌のペニシリン而性については種々検討され ているところであるが，秋葉教授によると，ペニシリン $\mathrm{Gl} \mathrm{mcg/cc}(\because 1.6 \mu / \mathrm{cc})$ 加培地に 增殖寸る 菌株をるつ て耐性株之見做すとされている。本訊験では $5.0 \mu / \mathrm{cc}$ 以 上の培地に発育する株を耐性株と見做すと，その成續は 50 株中，16株の発育をみた．即ち急性中耳焱 12 株中 3 株, 慢性中耳炎 38 株中 13 株であり，これを菌種別にみ ると, Mic. p. v. aureus 34 株中 11 株, Mic. p. v. albus 1 株火は認めず, Mic, citres 15 株中 5 株飞認めた。
從来ブドウ球菌のスルフフ剂耐性については問题とさ れていないが，臨床的に最近効果を認め難い症例を経駼 している，そこで本検查を施行した，チアゾルの有効 血中濃度は 3〜5mg\% とされている。サルゾールーS 10 $\mathrm{mg} \%$ 加培地上飞発育与る株学耐性株と見做すと，耐性 秼は 50 株中 13 株である。急性中耳炎 12 株中 3 株, 慢 性中耳焱 38 䋇中 10 株汇認めた. Mic. p. v. aureus 34 楼中 7 株, Mic. p. v. albus, 1 株中 1 株, Mic. citreus 15 株中 5 株に発育をみた。

第 5 節 臨床との関媇

（1）中耳分泌液の性状：Micrococcus 単感染による 急性中耳炎 31 例について，中耳分泌液を棌取検查した 成續恃第9表のようである。

第9表 中耳分泌液の出及び性状

\begin{tabular}{|c|c|c|c|c|c|}
\hline & 黄 色 & 14 & & 水根性 & 6 \\
\hline & 白色 & 4 & 性 & 货液性口 & 4 \\
\hline 2 & 緑色 & 1 & & 粘液性 1 & 13 \\
\hline & 桻 色 & 11 & 㭊 & 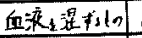 & 3 \\
\hline & 透明又, 付车透明 & 11 & & 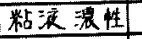 & 6 \\
\hline & 竐 & 31 & & 詰 & 31 \\
\hline
\end{tabular}

Mic. p. v. aureus と雖も中耳腔より採取した時の膿 では特有な色を呈さなかつた。

臭気，一般に悪臭は軽度であつた。

色及び性状のみでは本菌と判定することは困難であつ た。

（2）年令的関伱：第10表の上うである.

第 $\mathbf{1 0}$ 表 年令との関係

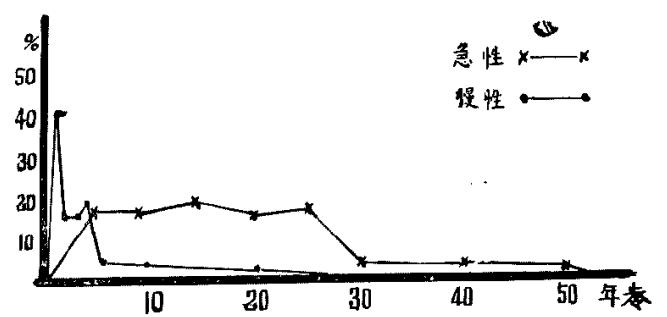

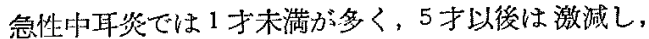
慢性中耳炎では 5〜25 才の閒に多く30才以後のもの には著しく減少していた。

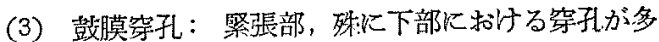
々，弛部恃全症例中 8 例で，䈌 11 表のようで西る。 急性中耳炎の Micrococcus による場合の穿孔は小且 
第 11 表 鼓膜穿孔の部位と大さ

\begin{tabular}{|c|c|c|c|c|c|c|c|c|c|}
\hline & \multicolumn{4}{|c|}{ 急、性中耳炽 } & \multicolumn{4}{|c|}{ 慢性中耳哭 } \\
\hline & & 荲感 & 泚感 & 計 & $\%$ & 毭感 & 湘感 & 㖕 & $\%$ \\
\hline 鼓 & 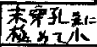 & g. & 6 & 15 & 250 & 4 & 1 & 5 & 4.9 \\
\hline 鿇 & 栗粒大 & 24 & 13 & 37 & 61.7 & 17 & 6 & 23 & 27.5 \\
\hline$\pi$ & 半来标大 & 3 & 3 & 6 & 10.0 & 14 & 9 & 23 & 22.5 \\
\hline 張 & 米粒大 & 2 & & 2 & 3.3 & 15 & 7 & 22 & 21.6 \\
\hline$i_{3}$ & 樓めて大 & & & & & 5 & 3 & 8 & 7.9 \\
\hline & 全穿孔 & & & & & 7 & 5 & 12 & 11.7 \\
\hline & 膜弛部 & & & & & 6 & 乙 & 8 & \\
\hline
\end{tabular}

1 カ所の例が多い，乳奻見に打いては特に小なる例が多 く，穿孔が急速に抠大寸るよらなことは稀であつた・慢 性中耳资に怙ける穿孔は粟粒大から米粒大の症例が多く 極めて大又仕全穿孔例は少なからた．弛部穿孔は僅か8 例であつた。

（4）Micrococcusを検出した急性中耳炎の予後： 于後は一般に良好で同ら後貽症を残さないものが多い， しかし単感染 31 例中 7 例は治瘉が遷延し，2 例の慢性 化をみた．混合感染例では 12 例中 3 例の慢性化の傾向 を示した。これを表示すると第 12 表のようである。

第 12 表 急性中耳炎の転㷌

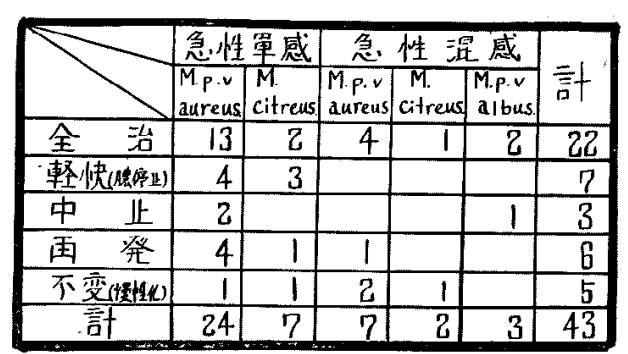

（5）慢性症例における菌の变䙴：Micrococcus を 詞:明した中耳炎について, 長期間に亘り数回の菌検查を 施行した数例をこっに举げると第13表のようである。

症例 1 及び 2 は 2 年間に亘る 観察で, 耳漏発来の都 度, 細菌検査を施行した症例である, 症例 3 は2〜3カ 月間滆に定期的に，余り訴党もなく耳漏を発来した症例 で，孚奻罗中耳炎中にこの型の中耳炎を多く訨明した。

症例 4 及び 5 のよらに臨床所見や経過よりムコーズス 中耳炎と思われ，更に特に Dip. Pn. II を㹬明する。， Micrococcus に覆われている例. 又, 逆に他の発育の 良好な菌に隠蔽されながらも存在している疛例 6,7 の
第 13 表 慢性症例に括ける菌の変避

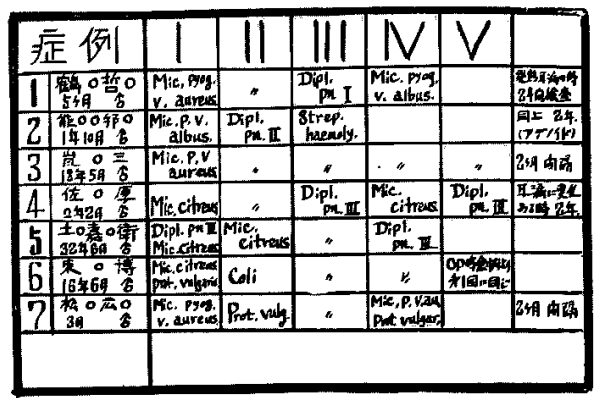

ような例もあつた。

\section{第 4 章 総括並に考按}

Mic. pyogenes の分類については说来形態と色素産 生を゙主とし, 溶血性, スタヒロキナ゙ーゼ, 白血球誘因作 用，皮虞毒，スタとロトキシンエエンテロトキシン，热 抗性，動物に対する病原性，その他生物学的検查及び式 験を行い，本菌と診断していたが，前述のような諸検查 を多数，行うことは容易でなく，分離培賈中斯に分類さ れる方法として Hucker の策分類法が提唱された。

本分類法は形態，色素産生と少数の生物学的性状に上 り分類する方法である。

この分類法の利点とするところは球菌を詳䋖に分類 し，且病原性の有無をで泆定でき，系統的に分類されて 行くことで, 数種の培地上の成績で分けられることにあ る. 病原性のある菌種は好気性で 5 種, 嫌気性で 4 程と されている。

しかし余り簡明に分類されており，菌㯖の異つた項に 入る場合もあるらと思われる．そこでわたくしは他の試 唡を併用，本分類の検討を試みた。

分類上 Mic，p. v. aureus と決定されながら，Coagulase test 疑陽性の成績を示寸菌株について，動物試験 を施行した．その結果病原性を示さない菌株むあつた。 この新分類法は完全とはいえないまでる，耳科臨床と細 菌学的臨床検査とを結ら゙方法としては満足すべきるのと 思われる。

楽洞酎性の問題. Pe に対するブドウ球菌の耐性発現 の機序，篗得の状況，更にこれが治療について多くの研 究がみられ，耳科臨床上に打いてる大きな問題であろら と考えられる。

$\mathrm{Pe} 30$ 万単位滗注. 1 時間後の血中濃度は約 $2.5 \sim 3.1$ $\mu / \mathrm{cc}$ である.勿諭人体内においては Pe のみで細菌の 発育を阻此し，更に菌を殺するのではない，又血中漄度 
にも限度がある、秋葉教授の $1.0 \mathrm{mcg} / \mathrm{cc}(\fallingdotseq 1.6 \mu / \mathrm{cc})$ は臨床的にも意義梁いるのと思われる。

in vitro 検查に括いて $5.0 \mu / \mathrm{cc}$ の培地侁育充する $\mathrm{Mi}$ crococcus を耐性株と見做守と，この検查によると急性 中耳炎では $25.0 \%$. 慢性中耳炎では $34.2 \%$ に耐性株を 認めた。

スルフア剂については淋菌や赤脷菌のように問題とな つていないが，中耳炎においても本戍が常に用いられる とつもに同一系統であるるのが使用されている点から大 きな問題であろらと思ら。

現今军々用いられる薬物はチアゾール采のものが最む 多い.スルフフチフゾールの有効血中浱度は 3〜 $5 \mathrm{mg} \%$ とされている.検出 Micrococcus 50 株について検する に $10 \mathrm{mg} \%$ 培地炕発育するるの $26.0 \%$ ，急性中耳炎で は25.0\%，慢性中耳炎では $26.3 \%$ であつた。

今後に和けるペニシリン及びスルフア剂等による化学 療法には一考を要するものがあり，使用薬物上臨床経過 を慎重に観察し，徒に同一葲物を萑荫使用することは厳 に戒むべきものと思われる。

本菌を去の分泌液から分離し得た中耳炎の臨床所見を 見るに，分泌夜の色並に性状と Micrococcus の種顛と の間には一定の関係を認めなかつた。

年令的には急性中耳炎においては 1 才末満の乳奻紧に 最子多く検出された．5才以後にば激減し，慢性中耳炎 では5 25才の間に多く、30才以啳のるのは著しく少 ない.

鼓膜穿孔の大さに関しては急性中耳炎では粟粒大のも のが最も多く，急性に穿孔の抬大するような例は稀であ つた，慢性中耳炎に执いては全穿孔例 $19.6 \%$. 弛部穿孔 は7.9\%にみた。

本菌を検出した中耳资中約 3 分の 1 は病原性を持たな い Micrococcus であつた.

本菌による急性中耳焱の予後は一般に良好で何等の後 胎症をる残さないものが多い. しかし単感染 31 例中 7 例は治㾑が遷延し，2例は全く慢性化した。就中混合感 染では 12 例中 3 例の慢性化の傾向を示した。素より中 耳炎の慢性化については要素が単一なるのではないが， この成績からみると，本菌は中耳焱の慢性化に一要約た るを失わないよう思われる。

慢性症例の菌の変遷についてい数例を挙げた。このう ち間姤的に耳涓をきたす第 3 例はバクテリオフフージの 形成と菌の消長の問題が考兵られ，わたくし等はこの問 題について実験中であるが，フフージの形成に伴い細菌
及び耳漏は消失し、フフージの消失又は減退後再び膿が 漏出するようである。このような場合膿の停止した後の 治療いかんによつて根治せしめ得るようである。この点 留意すい゙きことの一つと考察する。

\section{第 5 章 結 語}

急性中耳炎及び慢性中耳炎の中耳分泌液上り Micrcooccus を検出した 162 例について細菌学的炕，耳科学 的汇観察を行い,っぎのような結果を得た。

Hucker \& Hall そよる新分類法によると 162 株の Micrococcus 中 112 株が病原性菌で, 50 株が非病原性 株であつたこれを動物試験，その他の検査により病原 性再愉討するに，病原株 106，非病原株 56 の成續を 得た。一部は相違したが，本分類法は明璄且迅速に分類 される点において，耳科臨床に满足すべき分類法であっ た。

椧出菌株についてペニシリン耐性を検するに，急性中 耳炎では 12 例中 3 例 $(25.0 \%)$, 慢性中耳炎では38 例中 13 例 (34.2\%). スルフアチアゾールに対しては，急性中 耳炎 12 例中 3 例 $(25.0 \%)$, 慢性中耳炎 38 例中 10 例 (26.3\%) 飞薬洞耐性を有することを認めた。

本菌を検出し得た症例を年命的にみると，急性中耳炎 では 1 才未満の乳奻児に最も多く 5 才以㷋には激娍し， 慢性中耳炎では 5〜25才の間に多い。

本菌に上る急性中耳炎の予徭は一般に良好で何等の後 胎症も残さないものが多い，しかし単感染 31 例中 7 例 は治療が遷延し，2 例恃全く慢性化した. 就中混合感染 例では 12 例中 3 例の慢性化の傾向を示した。

治療にあたつては Micrococcus, 殊に Mic, pyogenes は化学製剂，抗生滆に耐性獲得が強いから慎重に行らべ きで，徒に同一薬物を萑葑使用することは厳に戒むい゙き ものと信ずる.

\section{文献}

1) Bergey, D.H.: Manual of Determinative Bactèriology 6th. 236, 1948. 2) 谷友次: 医学微生物学 2 版, 南山堂, 1950 . 3) 中村豊: 細菌学血清学検査 法, 克誠堂.4)伝染病研究所学友会編: 臨林細菌 学提要, 丸善. 5) 鳥居惠二：日本耳鼻咽喉科全書， 1 (3) 33，1953.6) 金九勇: 医学研究, 13 (11), $3135,1939.7$ ) 秋莱朝一郎: 日本細菌学雑誌, 7 (特 刚号)，365, 1952. 8) 柴田清人，石上浩一：猃断上 治療, 40 (5 6)，337，438，1952.99) 土垩俊夫, 高 橋鉄雄, 本間夫, 宫田澄: 日本細菌学雑誌, 7 (特別 号)，382，1952. 10）真下答明：日新医学, 36 (9), 
401，1941，11）千葉小二郎：成医会雑誌, $60(5,6)$ $582,621,1941$.

本論文の梗概は昭和 28 年 10 月 4 日, 日本耳鼻咽 喉科学会, 第 1 回中部地方連合会において 報告し た。

稿を終るに臨み終始御指導, 御校閲を睗つた恩師 谷友次教授, 国立金沢病院々長種村竜夫博士に深甚
なる謝意を表す「御援助御校閲下された，松田竜一 教授に深謝する.

なお，細菌検索にあたつては国立金沢病院研究㮞 査科細菌部主任伊藤博博士並に丸岡, 佐野技官, 西 田教授を始め 教室員各位の 御援助を心より感謝す る

（原稿到着 $=$ 昭和 35.12 .2 日）

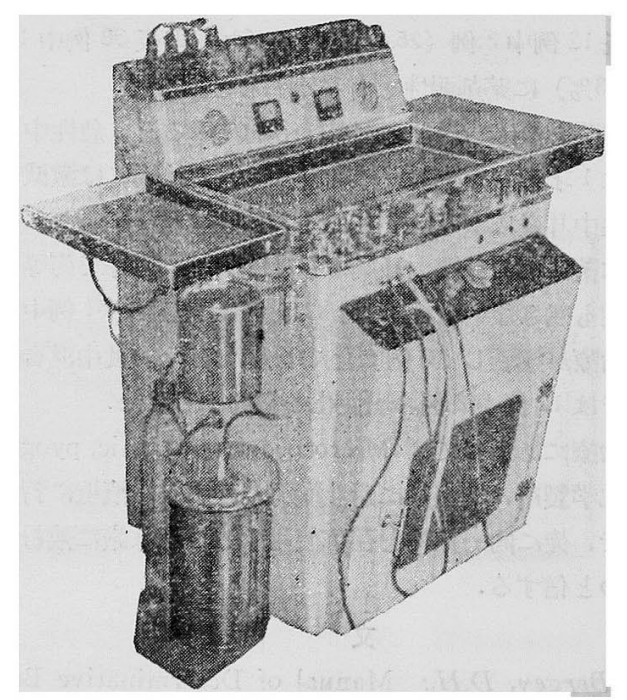

新規開業向の一般医療器械の新古 各種売買 交換・在庫豊富条件に 応じます。御相談下さい。

\section{MI耳鼻科ユニツト}

○業界一の価格低廉

○故障絶無

○アフター完備

別型寸法の御用命に応じます。 $¥ 90,000$.より $¥ 170,000$ 。で [乞御照会 係員参上]

（）各種モーター修理を迅速・安価に、 又、出張修理も致します。 いわしや有限 岩田醫療器商会 東京都文京区金助町 41 T E L (921) 2788 